\title{
ANALISIS SWOT UNTUK STRATEGI PENGEMBANGAN OBYEK WISATA PEMANDIAN MUAL MATA KECAMATAN PEMATANG BANDAR KABUPATEN SIMALUNGUN
}

\author{
Fitra Delita1, Elfayetti ${ }^{1}$, Tumiar Sidauruk ${ }^{1}$ \\ 1 Jurusan Pendidikan Geografi Fakultas Ilmu Sosial Universitas Negeri Medan \\ Jl. Willem Iskandar Psr V Medan Estate Medan, 20211 Indonesia \\ Email : delitafitra@gmail.com
}

\begin{abstract}
Abstrak
Penelitian ini bertujuan untuk menganalisis kekuatan, kelemahan, peluang dan ancaman dalam pengembangan objek wisata alam Pemandian Mual Mata yang terletak di Desa Bandar Meriah, Kecamatan Pematang Bandar, Kabupaten Simalungun. Kemudian dirumuskan strategi untuk pengembangan dengan cara meminimalkan kelemahan dan ancaman, memaksimalkan pendayagunaan peluang dan kekuatan. Data dikumpulkan melalui studi kepustakaan, observasi serta wawancara dengan stakeholder seperti Dinas Pariwisata, Bappeda, camat, kepala desa, tokoh masyarakat, masyarakat dan pengunjung. Data dianalisis secara deskriptifkemudian untuk menentukan strategi pengembangan objek wisata alam Pemandian Mual Mata dilakukan dengan analisis SWOT. Berdasarkan hasil penelitian maka dapat disimpulkan strategi pengembangan objek wisata alam Pemandian Mual Mata antara lain membangun sarana prasarana seperti akses jalan, alat angkut dan sarana akomodasi, membuat atraksi wisata dan promosi obyek wisata, mengembangkan produk wisata, serta melibatkan masyarakat dalam pengelolaan wisata.
\end{abstract}

Kata kunci: Strategi, Pengembangan, SWOT

\section{PENDAHULUAN}

Indonesia memiliki potensi yang besar untuk menghasilkan devisa dari sektor pariwisata. Hal ini dikarenakan sumber daya utama sebagai pendukung kemajuan pariwisata yang dimiliki oleh Indonesia. Pariwisata adalah salah satu dari industri gaya baru, yang mampu menyediakan pertumbuhan ekonomi yang cepat dalam hal kesempatan kerja, pendapatan, taraf hidup dan mengaktifkan sektor produksi lain di dalam negara penerima wisatawan (Wahab, 2003). Menurut Kementrian Kebudayaan dan Pariwisata (2011) sektor ini penyumbang devisa nomor 5 (2008), nomor 4 (2009) dan nomor 5 kembali pada tahun 2010 (setelah migas, minyak kelapa sawit, batubara dan karet olahan). Berdasarkan LAK Kemenpar tahun 2015, data statistik per Januari Desember 2015 menunjukkan capaian pembangunan pariwisata Indonesia mampu melampaui target yang telah ditentukan. Hal ini dibuktikan melalui kunjungan wisatawan mancanegara yang meningkat menjadi 10,4 juta orang, dari target 2015 sebesar 10 juta orang. Adapun kunjungan wisatawan mancanegara tersebut berkontribusi terhadap penerimaan devisa sebesar Rp 144 triliun. Kemenpar memprediksi bahwa tahun 2020 sektor pariwisata akan menjadi penyumbang devisa nomor 1 di Indonesia.

Peningkatan pencapaian devisa tersebut justru terjadi ketika devisa dari komoditi batu bara dan migas cenderung mengalami penurunan. Sementara itu, jumlah perjalanan wisatawan nusantara telah mencapai 255 juta perjalanan, dengan total pengeluaran wisnus sebesar Rp 224.68 Triliun. Jumlah penyerapan tenaga kerja diperkirakan mencapai 11,3 juta orang. Tidak hanya itu, branding Wonderful Indonesia pada 
tahun 2015 naik 100 peringkat, dari semula tanpa peringkat menjadi peringkat ke -47 , serta diraihnya berbagai penghargaan internasional untuk beberapa kategori, seperti; UNWTO Award 2015, ASEANTA Award 2015, World Halal Destination 2015 (Kementerian Pariwisata, 2015).

Provinsi Sumatera

Utara mempunyai 33 Kabupaten. Obyek wisata yang paling diprioritaskan pengembangannya oleh pemerintah adalah Danau Toba. Danau Toba merupakan salah satu dari 10 destinasi wisata prioritas tahun 2016 selain Borobudur, Mandalika, Labuan Bajo, Bromo-Tengger-Semeru, Kepulauan Seribu, Wakatobi, Tanjung Lesung, Morotai, dan Tanjung Kelayang (Rimanews, 2016). Danau Toba secara administratif dikelilingi oleh tujuh kabupaten yaitu Kabupaten Dairi, Kabupaten Simalungun, Kabupaten Samosir, Kabupaten Humbang Hasundutan, Kabupaten Toba Samosir, Kabupaten Karo, dan Kabupaten Tapanuli Utara. Akan tetapi potensi wisata di Sumatera Utara tak hanya dimiliki oleh Danau Toba. Setiap kabupaten memiliki obyek dan daya tarik wisata yang berbeda-beda, baik wisata alam maupun wisata budaya dan sejarah.

Kabupaten Simalungun sebagai salah satu kabupaten yang berada disekitar Danau Toba juga memiliki potensi pariwisata yang lain yaitu Pemandian Mual Mata pada Kecamatan Pematang Bandar. Pemandian Mual Mata adalah pemandian alam yang airnya sangat jernih, segar dan berasal dari mata air. Pengunjung yang datang ke Pemandian Mual Mata ini berasal dari berbagai tingkat usia terdiri dari anak-anak, remaja dan orang tua yang pada umumnya adalah warga sekitar atau yang berdomisili di Kabupaten Simalungun.

Pemandian ini masih tampak alami tanpa pembangunan fisik seperti obyek wisata yang lain. Belum banyak orang yang mengenal pemandian ini karena memang belum begitu diekspos ke masyarakat luar Kabupaten Simalungun. Padahal jika obyek wisata ini dikembangkan maka akan menambah pendapatan daerah serta meningkatkan perekonomian masyarakat sekitar. Untuk itu perlu dilakukan kajian mendalam untuk mengetahui kekuatan (strenght), kelemahan (weakness), peluang (oppurtunities) dan ancaman (threat) atau analisis SWOT sebagai rumusan strategi pengembangan obyek wisata Pemandian Mual Mata di Kecamatan Pematang Bandar, Kabupaten Simalungun, Provisnsi Sumatera Utara.

\section{METODE PENELITIAN}

Jenis penelitian yang digunakan dalam penelitian ini adalah deskriptif kualitatif. Iskandar (2008) menjelaskan penelitian deskriptif kualitatif adalah pendekatan sistematis dan subjektif dalam menjelaskan segala sesuatu yang ada di lapangan (bersifat empiris) serta berorientasi kepada upaya untuk memahami fenomena secara menyeluruh.

Lokasi penelitian ini adalah Pemandian Mual Mata di Kecamatan Pematang Bandar Kabupaten Simalungun. Data yang digunakan bersumber dari data primer dan data sekunder. Data primer diperoleh melalui observasi, wawancara, dan dokumentasi yang dilakukan dengan Dinas Pariwisata, Bappeda, camat, kepala desa, tokoh masyarakat, masyarakat dan pengunjung. Sedangkan data sekunder diperoleh melalui Badan Pusat Statistik (BPS), BAPPEDA dan Dinas Pariwisata, Kantor Camat dan Kepala Desa. Selanjutnya untuk menentukan strategi pengembangan objek wisata dilakukan analisis SWOT (Strengths/ kekuatan, Weakness/ kelemahan, Opportunities/ peluang, dan Threats/Ancaman).

Informan penelitian ini terdiri atas (1) Dinas Pariwisata dan Budaya Kabupaten Simalungun, (2) BAPPEDA Kabupaten Simalungun, (3) Camat Pematang Bandar, (4) Kepala Desa Bandar 


\section{ge Ografi}

Meriah, (5) Tokoh masyarakat

Masyarakat sekitar objek wisata,

Pengunjung objek wisata.

Teknik analisis data merupakan proses sistematis pencarian dan pengaturan transkripsi wawancara, catatan lapangan, dan materi-materi lain yang telah dikumpulkan sehingga dapat meningkatkan pemahaman mengenai materi-materi dan dapat menyajikan yang sudah peneliti temukan kepada orang lain (Emzir, 2008). Adapun teknik analisis data dalam penelitian ini dapat dilakukan melalui prosedur atau beberapa tahap sebagai berikut: (1) Reduksi; Data yang diperoleh dikumpulkan dan diseleksi, mana yang betul-betul dibutuhkan sebagai data utama dan data pelengkap. Lalu ditulis dalam bentuk uraian, difokuskan pada hal-hal yang penting secara
Available at http://jurnal.unimed.ac.id/2012/index.php/geo e-ISSN: 2549-7057 | p-ISSN: 2085-8167

sistematis sehingga lebih mudah dimengerti. (2) Model data (data display) ; Model data ini merupakan suatu kumpulan informasi yang tersusun dari pendeskripsian dan pengambilan tindakan. Bentuk dari model data lebih bersifat naratif dengan mengunakan matriks SWOT. Matriks SWOT merupakan alat yang dipakai untuk menyusun strategi pengembangan objek wisata. Matriks SWOT ini dapat menggambarkan secara jelas bagaimana peluang dan ancaman yang dihadapi sehingga dapat disesuaikan dengan kekuatan serta kelemahan yang dimiliki pariwisata. Melalui matriks SWOT dapat ditetapkan strategi pengembangan yang tepat. Matriks ini dapat menghasilkan empat sel kemungkinan alternative strategis, untuk lebih jelasnya dapat dilihat pada tabel 1 dibawah ini:

Tabel 1. Matriks SWOT

\begin{tabular}{|c|c|c|}
\hline & $\begin{array}{c}\text { Kekuatan } \\
(\text { Strengths-S) }\end{array}$ & $\begin{array}{c}\text { Kelemahan } \\
\text { (Weaknesses-W) }\end{array}$ \\
\hline $\begin{array}{c}\text { Peluang } \\
\text { (Opportunities-O) }\end{array}$ & Strategi SO & Strategi WO \\
\hline $\begin{array}{c}\text { Ancaman } \\
\text { (Threats-T) }\end{array}$ & Strategi ST & Strategi WT \\
\hline
\end{tabular}

Sumber : Wasistiono, dkk (2007)

Berdasarkan tabel di atas dapat dijelaskan bahwa SO adalah memanfaatkan seluruh kekuatan dengan memperhitungkan peluang, WO memanfaatkan kelemahan dengan memperhatikan peluang, ST adalah memanfaatkan kekuatan dengan memperhatikan ancaman, dan WT memanfaatkan kelemahan dengan memperhatikan ancaman. (3) Klasifikasi ; Data yang telah ada kemudian dikelompokkan sesuai dengan tema-tema yang muncul, sehingga mempermudah dalam analisis. (4) Kesimpulan ; Data yang diperoleh dicari maknanya dan diambil kesimpulan yang awalnya bersifat kabur dan diragukan. Namun jika sudah ditambah dengan kesimpulan, maka akan bersifat sempurna sehingga peneliti dapat memaparkan sesuai dengan fakta-fakta yang ada dilapangan secara sistematis dan sempurna.

\section{HASIL DAN PEMBAHASAN}

Pemandian Mual Mata merupakan sebuah pemandian alam yang berada di Desa Mariah Bandar, Kecamatan Pematang Bandar, Kabupaten Simalungun dengan daya tarik utama yaittu airnya yang sangat jernih, sejuk, berasal dari mata air dan pemandangan sekitar yang alamiah. Tiga buah mata air yang tak pernah kering yang ada di Desa Bandar Meriah ini adalah Mual Mata (pemandian umum), Mual Samosir (pemandian pria) dan Umbul (pemandian wanita). Sama seperti kedua pemandian lainnya, Pemandian Mual Mata belum banyak dikenal oleh masyarakat 
luar dari Kabupaten Simalungun. Hal ini dikarenakan kurangnya pengelolaan dan promosi wisata oleh pemerintah setempat. Setiap harinya pemandian ini hanya dikunjungi oleh masyarakat sekitar ingin berenang atau sekedar menikmati pemandangan.

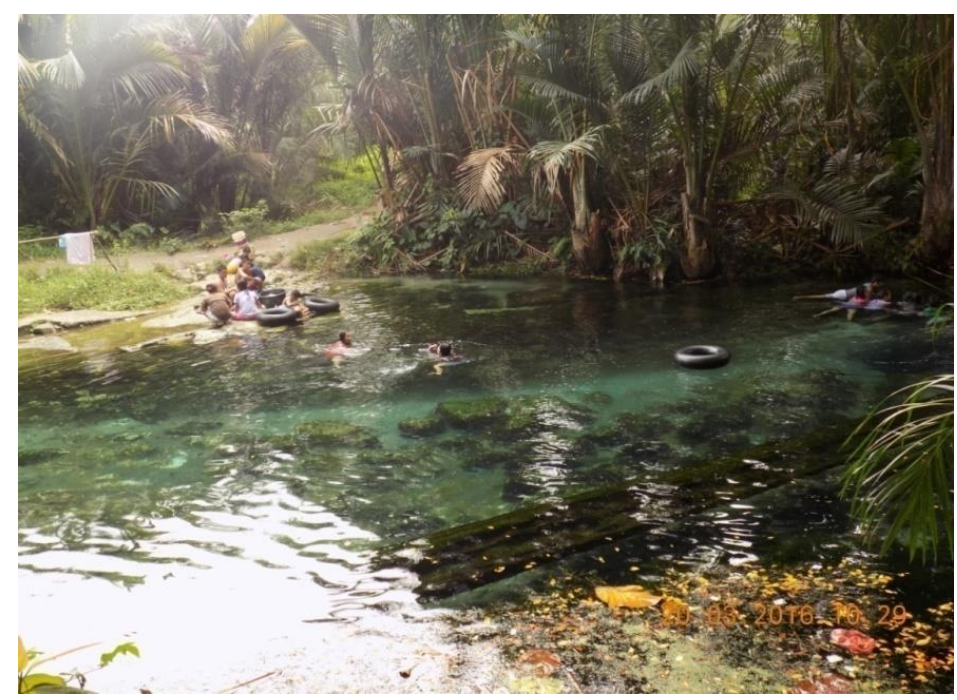

Gambar 1. Lokasi Pemandian Mual Mata

Untuk mencapai Pemandian Mual Mata ini tidaklah sulit. Pemandian ini terletak ditengah-tengah permukiman dan dikelilingi pohon kelapa sawit yang diselingi pepohonan yang rindang. Jika dari arah Siantar perjalanan dapat ditempuh dalam waktu 40 menit dan jika dari arah Kota Perdagangan dapat ditempuh dengan waktu 20 menit.

Dari Kota Medan menuju lokasi dapat menggunakan transportasi berupa mobil pribadi ataupun bus diantaranya Bus Intra, KUPJ, Karya Agung, dilanjutkan dengan menggunakan angkot dengan rute Siantar ke Desa Mariah Bandar yang berada dekat Kota Perdagangan a tau Pasar Kerasaan yang ada di Kecamatan Pematang Bandar.

Pemandangan menuju lokasi pemandian sangat menarik dimulai dari hamparan sawah dan rindangnya pepohonan di perkebunan. Sarana dan prasarana yang ada belum menunjang pengembangan obyek wisata alam ini. Kondisi jalan masih ada yang berlubang bahkan belum diaspal.

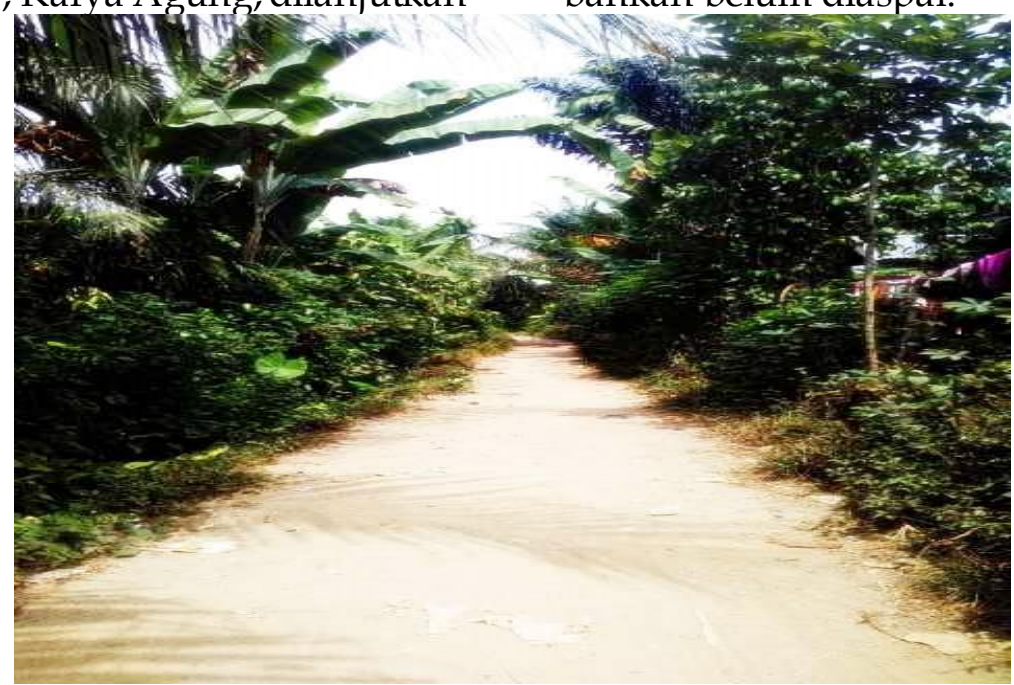

Gambar 2. Kondisi Jalan menuju Pemandian Mual Mata 
Dilokasi pemandian hanya ada warung sederhana yang menjual makanan ringan serta parkiran kendaraan yang dikelola pemuda setempat.

Perlu diciptakan masyarakat sadar wisata untuk pengembangan obyek wisata alam pemandian Mual Mata ini. Masyarakat sadar wisata merupakan masyarakat yang secara sadar dan bertanggung jawab berperan serta dalam mencapai sasaran pengembangan pariwisata dengan menggalang sikap dan tingkah laku sebagai tuan rumah dengan menerapkan sapta pesona dalam kehidupan sehari-hari. Sapta pesona yakni kondisi atau tujuh unsur yang dapat meningkatkan daya pariwisata.

Sikap dan tingkah laku masyarakat sekitar objek wisata sangat berpengaruh terhadap minat wisatawan datang ke objek wisata, untuk itu diperlukan strategi dengan memanfaatkan kekuatan internal untuk menghindari dampak ancaman eksternal dengan melakukan penyuluhan kepada maasyarakat mengenai sapta pesona, yang meliputi:

\section{1) Kondisi Aman}

Berdasarkan hasil observasi dan wawancara yang dilakukan, Pemandian Mual Mata sudah termasuk aman ini ditandai dengan tidak ada pengunjung yang kecopetan, tiak ada pengunjung yang merasa terggangu dengan pengamen, dan tidak ada gangguan dari pemuda atau pun penduduk setempat.

\section{2) Tertib}

Tertib merupakan kondisi yang sangat didambakan setiap orang termasuk wisatawan. Kondisi tersebut tercermin dari suasana yang teratur, rapi dan lancar serta menunjukkan disiplin yang tinggi dalam semua segi kehidupan masyarakat. Berdasarkan hasil observasi dan wawancara bahwa kondisi pada objek wisata Pemandian Mual Mata dapat dinyatakan kurang tertib karena pengunjung yang datang masih memarkir kendaraan sembarangan terutama pengunjung yang berasal dari warga sekitar.

\section{3) Bersih}

Bersih merupakan suatu keadaan atau kondisi lingkungan yang menampilkan suasana bebas dari kotoran, sampah, limbah, penyakit, dan pencemaran. Wisatawan akan merasa betah dan nyaman bila berada di tempattempat yang bersih dan sehat. Tujuan dari kebersihan adalah menciptakan lingkungan yang bersih bagi berlangsungnya kegiatan kepariwisataan yang mampu memberikan layanan higienis bagi wisatawan. Dari hasil observasi dan wawancara peneliti mendapatkan data bahwa kebersihan pada objek wisata Pemandian Mual Mata masih kurang ini ditandai dengan tidak tersedianya fasilitas tong sampah yang memadai dan masih kurangnya kesadaran akan kebersihan sehingga sampah banyak berserakan disekitar lokasi objek wisata.

\section{4) Sejuk}

Sejuk dapat tercermin melalui penciptaan lingkungan yang serba hijau, segar, rapi, nyaman, dan tentram baik di dalam maupun diluar ruangan. Kondisi yang sejuk pasti didambakan semua orang. Kondisi alam yang segar, enak dipandang mata, nikmat dihirup udaranya, dan mampu membawa pikiran anda kedalam nuansa ketenangan. Kondisi itulah yang dicari wisatawan dalam perjalanan wisatanya.

Hasil wawancara dan observasi dilapangan menunjukan bahwa objek wisata Pemandian Mual Mata merupakan objek wisata yang sejuk dan nyaman, dikatakan sejuk dan nyaman karena dilokasi objek wisata terdapat pohonpohon yang rindang dengan pemandangan yang hijau yang memberikan hawa sejuk disekitar objek wisata, gemericik air yang mengalir di Pemandian Mual Mata dan angin sepoi- 
sepoi yang menghembus rindangnya pepohonan menambah kesejukan dan ketenangan bagi pengunjung yang datang.

\section{5) Indah}

Keadaan atau suasana yang menampilkan lingkungan yang menarik dan sedap dipandang mata disebut indah. Indah dapat dilihat dari berbagai segi seperti dari segi tata warna, tata letak, tata ruangan, tata bentuk, atau pun gaya atau gerak yang serasi dan selaras sehingga memberikan kesan yang enak dan sedap dipandang mata. Pemandian Mual Mata memiliki keindahan yang alami belum terdapat pembangunan fisik buatan.

\section{6) Ramah}

Tujuan dari ramah adalah menciptakan lingkungan yang ramah bagi berlangsungnya kegiatan kepariwisataan yang mampu menawarkan suasana yang akrab, bersahabat serta seperti di "rumah sendiri" bagi wisatawan, sehingga mendorong minat kunjungan ulang dan promosi yang positif bagi prospek pasar yang lebih luas.

Sikap ramah dapat terwujud dengan bersikap sebagai tuan rumah yang baik dan rela membantu wisatawan, memberi informasi tentang adat istiadat secara sopan, para petugas bisa menampilkan sikap dan perilaku yang terpuji, menampilkan senyum dan

keramahtamahan yang tulus. Keramah tamahan erat kaitanya dengan masyarakat sadar wisata. Masyarakat sekitar objek wisata Pemandian Mual Mata masih belum sepenuhnya bisa dikatakan masyarakat yang sadar wisata karena tidak begitu peduli dengan pengunjung yang datang apalagi memberikan pelayanan.

\section{7) Kenangan}

Kenangan adalah ingatan atau pun kesan positif yang tersimpan atau melekat dan kuat pada ingatan pikiran seseorang yang disebabkan oleh pengalaman yang diperolehnya. Kenangan bertujuan menciptakan memori yang berkesan bagi wisatawan, sehingga pengalaman perjalanan/kunjungan wisata yang dilakukan dapat terus membekas dalam benak wisatawan, dan menumbuhkan motivasi untuk berkunjung ulang. Kenangan dapat terbentuk dengan berbagai atraksi yang menarik, menyajikan makanan dan minuman khas lokal yang bersih, sehat dan enak, menyediakan cenderamata yang menarik, unik/khas serta mudah dibawa, memiliki beragam atraksi yang menarik, menggali dan mengangkat keunikan budaya lokal.

Observasi dan wawancara yang peneliti lakukan dengan pengunjung pedagang dan pengelola objek wisata menyatakan kalau kenangan dari objek wisata Pemandian Mual Mata sangat kurang. Hal ini di tunjukkan dengan tidak adanya pedagang yang menjual makanan khas, tidak adanya atraksi wisata, dan tidak ada pedagang yang menjual cindera mata di lokasi objek wisata ini.

Strategi pengembangan objek wisata merupakan upaya dan usaha-usaha dalam mengembangkan objek wisata ke arah yang lebih maju. Dalam strategi pengembangan diperlukan identifikasi kelengkapan unsur-unsur pariwaisata. Unsur-unsur pariwisata berguna dalam menentukan kekuatan, kelemahan, peluang dan ancaman desa sehingga dapat dilakukan strategi yang tepat dalam pengembangan. Untuk mengetahui kekuatan, kelemahan, peluang dan ancaman desa maka peneliti melakukan wawancara.

Orang yang diwawancarai adalah tokoh masyarakat, dinas pariwisata, pengelola objek wisata, pengunjung, masyarakat dan orang-orang yang memiliki wawasan serta pengetahuan tentang objek wisata Pemandian Mual Mata sehingga diperoleh informasi yang detail, lengkap, dan akurat. Orang-orang yang diwawancarai memiliki pandanganpandangannya sendiri terhadap pengembangan yang akan dilakukan pada Pemandian Mual Mata. 
Berdasarkan hasil observasi wawancara maka diperoleh informasi tentang kekuatan, kelemahan, peluang dan ancaman yang dimiliki oleh objek wisata Pemandian Mual Mata. Kekuatan pada objek wisata Pemandian Mual Mata timbul dari dalam objek wisata itu sendiri, seperti: keunikan air yang jernih dan sejuk diselingi pohon-pohon yang rindang. Kesejukan udara dilokasi Pemandian Mual Mata dengan banyaknya pepohonan yang tumbuh disekitar lokasi objek wisata menjadi salah satu daya tarik dari wisata alam yang bisa dimanfaatkan oleh wisatawan untuk melepaskan lelah karena kesibukan sehari-hari. Sumber air yang melimpah dan selalu tersedia sepanjang tahun baik musim kmarau maupun musim penghujan bisa dimanfaatkan dalam pengembangan objek wisata Pemandian Mual Mata dalam membangun berbagai atraksi wista air.

Lokasi objek wisata yang jauh dari rasa khawatir akan keselamatan jiwa dan harta bendanya adalah suasana yang sangat didambakan oleh pengunjung objek wisata. Objek wisata Pemandian Mual Mata sudah termasuk salah satu objek wisata yang aman, karena tidak ada kasus pencurian, tindak kekerasan, perkelahian dan aktifitas pengamen yang kadang membuat pengunjung merasa jengkel dengan sikap yang tidak mau pergi sebelum diberi uang.

Selain kekuatan, objek wisata Pemandian Mual Mata juga memiliki kelemahan yang harus diperhatikan. Kelemahan ini merupakan alat evaluasi dalam pengembangan objek wisata. Yang menjadi kelemahan dari objek wisata ini adalah fasilitas umum yang tidak tersedia, hal ini membuat pengunjung objek wisata merasa tidak nyaman berada pada lokasi objek wisata karena fasilitas umum seperti Wc, mushola dan tempat ganti baju pada objek wisata air sangat di butuhkan sebagai fasilitas dasar pada objek wisata karena fasilitas umum merupakan penunjang kebutuhan sehari-hari manusia. Tidak terawatnya fasilitas pada objek
Available at http://jurnal.unimed.ac.id/2012/index.php/geo e-ISSN: 2549-7057 | p-ISSN: 2085-8167

berdampak pada ketidaknyamanan pengunjung.

Belum adanya pembangunan sarana dan prasarana obyek wisata Pemandian Mual Mata. Kekurangan ini semakin membuat pengunjung tidak merasa puas berkunjung ke lokasi objek wisata Pemandian Mual Mata. Tidak tersedinya sarana seperti restoran/rumah makan, yang ada hanya warung sederhana yang menyediakan mie instan membuat pengunjung harus makan di tempat lain atau membawa makanan sendiri dari rumah.

Keterbatasan sarana seperti hotel/ penginapan membuat pengunjung tidak bisa menghabiskan waktunya lebih dari 24 jam di lokasi objek wisata ini. Walaupun tidak dibangun hotel yang mewah, rumahrumah penduduk pun bisa dijadikan penginapan sementara untuk pengunjung, tapi belum ada masyarakat yang melakukan hal tersebut. Hal ini disebabkan kurangnya minat masyarakat untuk berbisnis dibidang kuliner dan penginapan, selain kurang berminat masyarakat setempat juga kurang paham bagaimana memanfaatkan peluang di bidang bisnis.

Transportasi khusus atau angkutan umum lainnya yang tidak ada ke lokasi objek wisata membuat akses pengunjung ke lokasi objek wisata menjadi terhambat. Hal ini membuat kurangnya pengunjung yang datang ke lokasi objek wisata Pemandian Mual Mata. Kurangnya tenaga professional dalam pengelolaan obyek wisata membuat objek wisata tidak terlalu menarik dimata pengunjung. Saat ini pengelolaan Pemandian Mual Mata diserahkan pada penduduk setempat. Dari pengamatan yang peneliti lakukan, pengelola objek wisata ini kurang terampil dalam mengelola lokasi objek wisata. Hal ini tampak jelas dengan tidak adanya pembangunan terhadap fasilitas-fasilitas yang dibutuhkan pengunjung.

Keterbatasan atraksi pada objek wisata Pemandian Mual Mata menjadikan objek wisata ini belum mampu menahan 
pengunjung untuk berlama-lama dilokasi objek wisata. Dilokasi Pemandian Mual Mata pengunjung datang dan pergi setelah berfoto-foto dan berenang, sebagian besar tidak memiliki keinginan untuk kembali lagi dalam waktu yang singkat. Hal ini menjadi penghalang bagi pedagang yang berada pada lokasi objek wisata. Dengan singkatnya kunjungan wisatawan maka tidak ada minat wisatawan untuk belanja dilokasi objek wisata. Hal ini ditambah lagi dengan masih belum terwujudnya masyarakat yang sadar wisata. Masyarakat pada lokasi objek wisata masih belum sepenuhnya sadar akan fungsi dan manfaat dari objek wisata. Belum seluruh masyarakat yang bisa menerima dan ramah terhadap pengunjung. Hal yang paling penting disini adalah tidak bersedianya masyarakat untuk memberikan lahan yang berada disekitar objek wisata Pemandian Mual Mata untuk dikelola pemerintah daerah untuk dijadikan lahan pengembangan objek wisata Pemandian Mual Mata.

Selanjutnya Peluang adalah kemampuan yang dimiliki suatu daerah untuk dapat dimanfaatkan dan berkembang dimasa yang akan datang. Peluang ini bertujuan untuk memajukan objek wisata. adapun peluang yang dimiliki oleh objek wisata Pemandian Mual Mata termasuk pada kawasan srategis dari fungsi dan daya dukung lingkungan. Jika Pemandian Mual Mata merupakan kawasan strategis Kabupaten Simalungun sehingga pengembangannya termasuk salah satu perencanaan yang diutamakan.

Adanya rencana pemerintah daerah untuk mengembangkan Pemandian Mual Mata, rencana pengembangan ini sudah tertuang dalam rencana tata ruang wilayah Kabupaten Simalungun. Adanya Otonomi daerah memberi keleluasaan untuk mengembangkan potensi wisata, kebijakan otonomi daerah memberikan kewenangan kepada daerah untuk menggali potensi sumber daya alam yang ada. Dengan pemanfaatan kemajuan teknologi informasi serta letak geografis.

Dari peluang maka akan muncul ancaman, ancaman berasal dari luar yang dapat mengancam pengembangan objek wisata Jembatan Pemandian Mual Mata. Adapun ancaman terhadap objek wisata Pemandian Mual Mata adalah berkembangnya obyek wisata lain yang meningkatkan persaingan, Banyaknya obyek wisata di Kabupaten Simalungun seperti Danau Toba yang memberikan variasi bagi pengunjung dan memacu pengembangan obyek wisata tersebut agar dapat menarik pengunjung Untuk dapat bersaing dengan obyek-obyek lain, Obyek Wisata Pemandian Mual Mata perlu inovasi-inovasi untuk menarik pengunjung yang merupakan tugas berat bagi pengelola obyek, maka dibutuhkan sumber daya manusia yang handal dan berkualitas.

Kerusakan lingkungan akibat pengembangan yang tidak tepat, merupakan ancaman yang disebabkan oleh manusia dan alam. Kesadaran pengunjung untuk ikut menjaga obyek merupakan hal penting agar pengunjung satu sama lainnya memperoleh kenyamanan dan menjaga keasrian obyek wisata. Dalam pengembangan pun perlu berhati-hati agar tidak merusak lingkungan.

Strategi pengembangan obyek wisata alam pemandian Pemandian Mual Mata dengan analisis dapat dilihat pada tabel berikut ini :

\begin{tabular}{|ll|}
\hline \multicolumn{3}{|c|}{ Kekuatan (Strength-S) } \\
\hline 1. & Keunikan dan keindahan objek \\
& wisata \\
2. & Sumber air yang melimpah \\
3. & Kondisi yang aman \\
4. Suasana yang memberikan \\
kenyamanan \\
5. Udara yang sejuk \\
6. $\begin{array}{l}\text { Merupakan kawasan strategis dari } \\
\text { fungsi dan daya dukung lingkungan }\end{array}$ \\
\hline
\end{tabular}


Kekuatan tersebut merupakan faktor pendorong dalam pengembangan obyek wisata alam Pemandian Mual Mata.

\begin{tabular}{|l|l|}
\hline Kelemahan (Weaknesses-W) \\
\hline 1. & Keterbatasan biaya anggaran \\
pengembangan objek wisata \\
2. \\
3. Turangnya sarana prasarana \\
4. Tidak ada atraksi pendamping \\
menuju lokasi objek wisata knusus \\
5. $\begin{array}{l}\text { Kurangnya perawatan terhadap objek } \\
\text { wisata dan fasilitas yang sudah ada }\end{array}$ \\
6. Tanah sekitar objek wisata masih \\
milik penduduk
\end{tabular}

Kelemahan tersebut bisa diatasi dengan merumuskan strategi pengelolaan oleh pemerintah dengan melibatkan masyarakat.

\section{Peluang (Opportunuties-O)}

1. Adanya rencana pemerintah daerah untuk mengembangkan Pemandian Mual Mata

2. Adanya Otonomi daerah memberi keleluasaan untuk mengembangkan potensi wisata

3. Terbukanya lapangan pekerjaan bagi masyarakat sekitar

4. Paket wisata karena berdekatan dengan objek wisata lain

5. Tingginya keinginan untuk berwisata dan berekreasi

\section{Ancaman (Threats-T)}

1. Berkembangnya obyek wisata lain yang meningkatkan persaingan

2. Kerusakan lingkungan akibat pengembangan yang seenaknya

3. Kurangnya kesadaran masyarakat sekitar Pemandian Mual Mata akan pentingnya keberadaan sebuah objek wisata.

Selanjutnya sesuai dengan kekuatan, kelemahan, peluang dan ancaman dapat dilakukan analisis SWOT. Strategi yang dilakukan dalam pengembangan objek wisata Bayang Sani dan Jembatan Akar sesuai analisis SWOT adalah dengan dengan menghasilkan empat alternatif strategi yaitu alternatif Strategi SO (ciptakan strategi yang mengunakan kekuatan untuk memanfaatkan peluang), alternative strategi WO (ciptakan strategi yang yang meminimalkan kelemahan untuk memanfaatkan peluang), alternatif strategi ST (ciptakan strategi yang mengunakan kekuatan untuk mengatasi ancama) dan alternatif strategi WT (ciptakan strategi yang meminimalkan kelemahan-kelemahan dan menghindari ancaman).

\section{a. Strategi SO (Strength and Opportunities)}

Strategi SO yaitu strategi yang mengoptimalkan kekuatan (Strenght) untuk memanfaatkan Peluang (Oportunities), alternatif dari srategi SO adalah:

1) Membangun dan memperbaiki sarana dan pemeliharaan prasarana wisata

Setiap Objek wisata yang dikujungi oleh wisatawan, tentu mereka menginginkan lokasi wisata yang menarik untuk dikunjungi, bukan hanya atraksi yang ditampilkan dari objek wisata akan tetapi sarana dan prasarana yang ada di kawasan objek wisata. Sarana prasarana kepariwisataan sangat berpengaruh terhadap meningkatnya jumlah kunjungan wisatawan datang ke objek wisata.

Jika wisatawan merasa kebutuhannya selama berada di daerah objek wisata tercukupi tentu akan menjadi kenangan tersendiri bagi pengunjung, dan adanya keinginan untuk kembali ke objek wisata tersebut. untuk itu disekitar ataupun dikawasan objek wisata perlu dibangunnya sarana prasarana pendukung kegiatan kepariwisataan guna keberlanjutan pariwisata di daerah tersebut, seperti membangun: restoran, tempat penjualan souvenir, bank, puskesmas, MCK, lahan parkir, tempat pengambilan karcis dan gazebo. 
Selain membangun dan mengadakan sarana prasarana objek wisata, memperbaiki dan memelihara sarana dan prasarana yang sudah ada juga sangat penting, tanpa perawatan sarana dan prasarana tentu tidak akan menarik pengunjung. Pemeliharaan dilakukan untuk mempertahankan keindahan sarana yang sudah rusak sehinnga bisa difungsikan lagi tanpa harus membuat yang baru dan bisa dimanfaatkan dalam jangka waktu yang panjang.

\section{2) Mengadakan Akomodasi Pariwisata} Akomodasi merupakan rumah sementara untuk beristirahat apabila mereka lelah selama wisatawan berada di daerah yang ia kunjungi, baik itu hotel, losmen maupun villa dengan kenyamanan dan pelayanan yang baik dan kebersihan sanitasinya. Semua fasilitas harus sesuai dengan kebutuhan wisatawan. Jumlahnya harus diperhitungkan berdasarkan jumlah dan lamanya wisatawan tinggal ditempat objek wisata.

\section{3) Mengembangkan Atraksi Wisata}

Atraksi wisata yang baik harus dapat mendatangkan wisatawan sebanyakbanyaknya, menahan mereka ditempat atraksi dalam waktu yang cukup lama dan member kepuasan kepada wisatawan yang datang berkunjung. Atraksi wisata selain yang disediakan oleh alam perlu dibangun atraksi pendamping pariwisata agar suasana dan keadaan objek wisata tidak membosankan.

Atraksi yang bisa di bangun pada objek wisata Pemandian Mual Mata umumnya adalah atraksi air. Pada atraksi Pemandian Mual Mata atraksi pendamping yang bisa dibangun seperti, tempat pemandian, arung jeram, Flying Fox, tempat pemancingan, dan tempat bermain anak.

4) Membangun dan mengadakan aksesibilitas wisata

Aksesibilitas adalah semua faktor yang dapat memberi kemudahan kepada wisatawan untuk berkunjung ke daerah tujuan wisata seperti: seperti tersedianya prasarana bandara, pelabuhan, terminal, stasiun kereta api, terminal, prasarana jalan, jembatan, dan trasportasi. Aksesibilitas merupakan prasarana yang paling penting dalam mendukung pengembangan pariwisata daerah, karena dengan akses jalan yang baik akan memberikan rasa nyaman kepada wisatawan untuk melaluinya tanpa ada rasa khawatir akan terjadinya kecelakaan.

Berdasarkan hasil interview dan survei lapangan menunjukkan bahwa jalan menuju Jembatan Akar dan Bayang Sani cukup bagus, licin dan beraspal tapi kondisi jalan semakin mendekati objek wisata jalan semakin menyempit, tentu faktor ini menjadi salah satu kelemahan bagi objek wisata Jembatan Akar dan Bayang Sani. Untuk itu diperlukan strategi dengan memanfaatkan peluang yang ada untuk mengatasi kelemahan dengan memperlebar jalan yang sempit. Selain jalan yang dapat mempermudah akses, sarana transportasi juga sangat berpengaruh terhadap kenyamanan perjalanan wisatawan untuk berkunjung ke daerah tujuan wisata. dengan jalan yang bagus tampa adanya transportasi perjalanan pengunjung menuju objek wisata akan terhambat.

Transportasi merupakan sarana pengangkutan yang dapat membawa wisatawan dari tempat tinggal menuju daerah lain atau tujuan wisata. Hal ini dapat dilakukan melalui udara, darat, dan kapal untuk memperlancar perjalanan. dengan menyediakan sarana transportasi khusus untuk mengantar wisatawan ke lokasi objek wisata maupun ke tempattempat lain yang berhubungan dengan aktivitasnya di daerah wisata yang dikunjungi. Dengan menghidupkan kembali pengusaha swasta dibidang angkutan umum untuk kembali beroperasi, bekerja sama dengan dengan pihak swasta seperti travel agent, baik yang berasal di propinsi ataupun diluar dan membuat paket-paket perjalanan wisata. 


\section{b. Strategi WO (Weaknesses and Opportunities)}

Strategi WO (Weaknesses and Opportunities) yaitu strategi yang meminimalkan kelemahan (Weaknesses) dengan memanfaatkan peluang (Opportunities) adalah:

1) Meningkatkan promosi dan memperbaiki program pengembangan lebih bagus untuk menarik pengunjung sehingga siap untuk menghadapi persaingan antar objek wisata

Promosi merupakan suatu cara atu strategi yang dilakukan oleh perusahaan untuk memperkenalkan produknya kepada khalayak ramai. Strategi meningkatkan promosi dimaksudkan untuk memanfaatkan peluang yang ada dalam mengurangi kelemahan belum berkembangnya suatu objek wisata.

Salah satu promosi yang bisa dilakukan adalah memanfaatkan eveneven pariwisata yang dirancang oleh pemerintah Pesisir Selatan sebagai sarana promosi dan pengenalan objek wisata Jembatan Akar - Bayang Sani kepada masyarakat dalam dan luar negeri. Promosi dapat dilakukan melalui media elektronik, surat kabar, spanduk dan pamplet.

2) Melakukan koordinasi dengan pihak swasta untuk menanamkan modal

Strategi ini dilakukan dengan tujuan untuk mendukung kelanjutan pembangunan agar dapat membantu membangun sarana prasarana, akomodasi, atraksi objek wisata pendamping dan saran alainnya yang belum disediakan secara professional. Maka untuk itu diperlukan koordinasi guna menarik minat investor atau pihak swasta dan pemerintah. Koordinasi dengan pihak swasta untuk menanamkan modalnya, Dengan membentuk ikatan kerjasama atas dasar kesepakatan dan rasa saling membutuhkan dalam rangka meningkatkan kapabilitas di suatu bidang usaha tertentu.

3) Melakukan pemberdayaan, penyuluhan agar menumbuhkan dan meningkatkan kesadaran masyarakat tentang pentingnya masyarakat Sadar Wisata

Masyarakat sadar wisata merupakan masyarakat yang secara sadar dan bertanggung jawab berperan serta dalam mencapai sasaran pengembangan pariwisata dengan menggalang sikap dan tingkah laku sebagai tuan rumah dengan menerapkan sapta pesona dalam kehidupan sehari-hari. Sapta pesona yakni kondisi atau tujuh unsur yang dapat meningkatkan daya pariwisata.

\section{c. Strategi ST (Strength and Treats)}

Strategi ST (Strength and Treats) yaitu strategi yang mengunakan kekuatan (Strength) untuk mengatasi ancaman (Treats) adalah:

1) Mengoptimalkan potensi alam dan keunikan objek wisata dengan mempertahankan dan pemeliharaan objek wisata secara berkesinambungan untuk menghadapi persaingan antar objek wisata

2) Pengembangan dan pembangunan objek wisata yang ramah lingkungan dengan melakukan kontrol yang tegas terhadap pelaksanaan unsur-unsur pelaku wisata yang tidak sesuai dengan sikap dan tindakan pelaku wisata yang dapat mengancam kerusakan objek wisata

3) Mengadakan objek wisata pendamping

Objek wisata pendamping sangat penting agar suasana pada Jembatan Akar memiliki bervariasi dan mampu menarik dan mempertahankan wisatawan untuk berlama-lama dilokasi objek wisata Jembatan Akar dan Bayang Sani 
d. Strategi WT (Weaknesses and Treats)

Strategi WT (Weaknesses and Treats) yaitu strategi yang meminimalkan kelemahan (Weaknesses) dan menghindari ancaman (Treats) adalah:

1. Peningkatan kualitas tenaga kerja professional dalam pengelolaan dan pemeliharaan objek wisata secara berkesinambungan sehingga mengurangi kerusakan lingkungan akibat pengembanggan yang seenaknya.

2. Melakukan pengawasan dan pemeliharaan fasilitas - fasilitas yang telah ada dilokasi objek wisata.

\section{KESIMPULAN}

Berdasarkan hasil penelitian maka dapat disimpulkan strategi pengembangan objek wisata alam Pemandian Mual Mata antara lain membangun sarana prasarana seperti akses jalan, alat angkut dan sarana akomodasi, membuat atraksi wisata dan promosi obyek wisata, mengembangkan produk wisata, serta melibatkan masyarakat dalam pengelolaan wisata. Jika segala kekuatan dan peluang ditingkatkan serta meminimalkan kelemahan dan menghindari ancaman dilakukan didukung oleh penerapan strategi pengembangan yang tepat maka obyek wisata alam Pemandian Mual Mata yang terletak di Desa Bandar Meriah, Kecamatan Pematang Bandar, Kabupaten Simalungun akan mampu bersaing dengan obyek wisata lainnya yang ada di Kabupaten Simalungun bahkan di Sumatera Utara.

\section{DAFTAR PUSTAKA}

Hermawan, Heri. 2008. "Analisis Pengembangan Kebijakan Pariwisata Indonesia (Studi Perbandingan Kebijakan Pariwisata Indonesia dengan Malaysia)". Jurnal Kepariwisataan Indonesia, 3 (1): 13-35
Pendit, Nyoman. 2002. Ilmu Pariwisata : Sebuah Pengantar Perdana. Jakarta : PT Pradnya Paramiata

Putri, T dan Ariani, M. 2011. "Penerapan Sadar Wisata dan Penguatan Citra Wisata Melalui Penanaman Tanaman Upakara di Kerambitan Kabupaten Tabanan". Jurnal Udayana Mengabdi, 10 (2): 90-94

Pitana, I Gede.2005.Sosiologi Pariwisata. Yogyakarta : ANDI

Roostika, Ratna. 2012. "Citra Merek Wisata dan Perilaku Wisatawan: Yogyakarta sebagai Daerah Tujuan Wisata". Jurnal Manajemen dan Akuntasi, 1 (1): 41-54

Ryalita, Sefira. 2009. "Analisis Strategi Pengembangan Pariwisata Daerah (Studi pada Dinas Kebudayaan dan Pariwisata Daerah Kabupaten Nganjuk)". Jurnal Administrasi Publik, 1(4): 135-143

Sugiyono. 2008. Metode Penelitian Pendidikan. Penerbit Alfabeta : Bandung

Undang-Undang RI Nomor 32 Tahun 2004. Tentang Pemerintah Daerah. Jakarta

Undang-Undang Nomor. 10 Tahun 2009 tentang Kepariwisataan. 2008. Surabaya: Diperbanyak oleh CV Pustaka Agung Harapan Surabaya.

Undang-Undang RI No.9 Tahun 1990. Tentang Kepariwisataan.Jakarta

Wahab, Salah. 2003. Manajemen Kepariwisataan. Jakarta: PT Pradnya Paramita

Yoeti, Oka. 1996. Pengantar Ilmu Pariwisata. Penerbit Angkasa : Bandung. 